\title{
Abnormal B-Cell and Tfh-Cell Profiles in Patients With Parkinson Disease
}

\author{
A Cross-sectional Study
}

Rui Li, MD, PhD, Thomas Francis Tropea, DO, Laura Rosa Baratta, BSc, Leah Zuroff, MD, MS,

Maria E. Diaz-Ortiz, BSc, Bo Zhang, MD, PhD, Koji Shinoda, MD, PhD, Ayman Rezk, PhD, Roy N. Alcalay, MD, MS, Alice Chen-Plotkin, MD, and Amit Bar-Or, MD

Neurol Neuroimmunol Neuroinflamm 2022;9:e1125. doi:10.1212/NXI.0000000000001125

\author{
Correspondence \\ Dr. Bar-Or \\ amitbar@pennmedicine.upenn.edu \\ or Dr. Chen-Plotkin \\ chenplot@pennmedicine.upenn.edu
}

\begin{abstract}
\section{Background and Objectives}

There has been growing interest in potential roles of the immune system in the pathogenesis of Parkinson disease (PD). The aim of the current study was to comprehensively characterize phenotypic and functional profiles of circulating immune cells in patients with PD vs controls.

\section{Methods}

Peripheral blood was collected from patients with PD and age- and sex-matched neurologically normal controls (NCs) in 2 independent cohorts (discovery and validation). Comprehensive multicolor flow cytometry was performed on whole blood leukocytes and peripheral blood mononuclear cells to characterize different immune subsets and their ex vivo responses.
\end{abstract}

\section{Results}

The discovery cohort included $17 \mathrm{NCs}$ and 12 participants with PD, and the validation cohort included $18 \mathrm{NCs}$ and 18 participants with PD. Among major immune cell types, B cells appeared to be preferentially affected in PD. Proliferating B cell counts were decreased in patients with PD compared with controls. Proportions of B-cell subsets with regulatory capacity such as transitional B cells were preferentially reduced in the patients with PD, whereas proportions of proinflammatory cytokine-producing B cells increased, resulting in a proinflammatory shift of their B-cell functional cytokine responses. Unsupervised principal component analysis revealed increased expression of TNF $\alpha$ and GM-CSF by both B cells and T cells of patients with $\mathrm{PD}$. In addition, levels of follicular T cells, an important B-cell helper T-cell population, decreased in the patients with $\mathrm{PD}$, correlating with their B-cell abnormality.

\section{Discussion}

Our findings define a novel signature of peripheral immune cells and implicate aberrant Tfh:Bcell interactions in patients with $\mathrm{PD}$. 


\section{Glossary}

AUC = area under the curve; $\mathbf{C U}=$ Columbia University; GWASs = Genome-wide association studies; IgG = immunoglobulin; IRBs = Institutional Review Boards; LEDD = l-dopa equivalent daily dose; $\mathbf{M H C}=$ major histocompatibility complex; NCs = normal controls; PBMCs = peripheral blood mononuclear cells; PC1 = principal component $1 ; \mathbf{P C A}=$ principal component analysis; PD = Parkinson disease; $\mathbf{S N}=$ substantia nigra; SOPs = standard operating procedures; $\mathbf{T h}=$ T-helper; $\mathbf{U P A}=$ University of Pennsylvania.

Parkinson disease $(\mathrm{PD})$ is a neurodegenerative disease that affects more than 6 million people globally. ${ }^{1}$ The etiology of $\mathrm{PD}$, which is characterized by a progressive loss of dopaminergic neurons, remains elusive. ${ }^{2,3}$ Emerging evidence suggests that immune system responses may be involved in PD pathogenesis. ${ }^{4}$ Genome-wide association studies (GWASs) relate haplotypes of the major histocompatibility complex (MHC) class II genes and other immune-related genes (e.g., TLR9, IL-1R2, SATB1, STAB1, GBA, CD38, CD19, NOD2, and FYN) to risk of developing the disease., ${ }^{5,6}$ Deposition of immunoglobulin ( $\mathrm{IgG}$ ) and infiltration of $\mathrm{CD} 4^{+} \mathrm{T}$ cells have been reported in the brains of both mouse models of PD and in patients with $\mathrm{PD}$, implicating both humoral and cellular immune responses. ${ }^{7,8}$

Studies of circulating immune cells in patients with PD have largely focused on $\mathrm{T}$ cells and have described $\alpha$-synucleinspecific autoreactive $\mathrm{T}$ cells ${ }^{9,10}$ and increased levels of $\mathrm{CD} 4^{+}$ T-helper (Th)17 cells (implicated as proinflammatory in other conditions) that are capable of mediating neuronal cell death in vitro.. ${ }^{11}$ Although helper $\mathrm{T}$ cells are important orchestrators of many immune responses in both health and disease, their functions are commonly shaped by interactions with other immune cell types such as myeloid cells and $\mathrm{B}$ cells. ${ }^{12}$ Indeed, abnormal profiles and functional responses of such non- $\mathrm{T}$ cells are increasingly implicated across a growing range of complex human conditions traditionally thought to be principally mediated by $\mathrm{T}$ cells, ${ }^{13-15}$ and therapeutic targeting of the non- $\mathrm{T}$ cells has been shown to reverse abnormalities in these diseases. ${ }^{16-18}$ Little is known, however, about potential interactions between $\mathrm{T}$ cells and non- $\mathrm{T}$ cells in patients with PD. Efforts to link across cell types require simultaneous analysis of phenotypic and functional profiles of both T-cell and non-T-cell populations.

Here, we developed and applied a multiparametric flow cytometry platform to comprehensively assess both phenotypic and functional profiles of multiple ( $\mathrm{T}$ cell and non$\mathrm{T}$ cell) immune cell types in 2 independent (discovery and validation) cohorts of patients with $\mathrm{PD}$ and neurologically normal controls.

\section{Methods}

\section{Standard Protocol Approvals, Registrations, and Patient Consents}

All subjects enrolled in this study provided informed consent as part of protocols approved by the University of Pennsylvania
(UPA) and Columbia University (CU) Institutional Review Boards (IRBs) and in compliance with the Declaration of Helsinki principles.

\section{Subjects and Study Design}

Two independent cohorts of both patients with Parkinson disease (PD) and normal controls (NCs) from the 2 institutions enabled discovery and validation of findings. eTable 1 provides an overview of the cohorts. eTable 2 provides basic and clinical demographics for each patient. UPenn Discovery Cohort blood samples (NC, $\mathrm{n}=17$; PD, $\mathrm{n}=12$ ) were collected between October and December 2017, and the Validation Cohort samples (NC, $\mathrm{n}=18 ; \mathrm{PD}, \mathrm{n}=18$ ) were collected between July and September 2018. All individuals with PD met the diagnostic criteria of the United Kingdom Parkinson's Disease Brain Bank as previously described for these clinical cohorts. ${ }^{19}$ All normal controls had no known neurologic disorder. None of the participants had any suggestion of acute or chronic infection or on any immunemodifying therapy.

\section{Sample Processing and Cell Culture}

Antecubital venous blood was obtained contemporaneously from neurologically normal controls and participants with PD and used for fresh whole blood analysis and subsequent analysis of peripheral blood mononuclear cells (PBMCs) that were isolated by Ficoll density centrifugation (GE Healthcare) and then cryopreserved. All samples were processed at the University of Pennsylvania, with samples from the Columbia University samples (both NC and PD) overnight shipped to the University of Pennsylvania for next-day analysis and processing, using Credo Box shippers (Pelican BioThermal) that ensure temperature stability during transport. All steps of sample handling, shipping, processing and storage, and whole blood staining and PBMC assays were performed using the identical standard operating procedures (SOPs). Although the fresh whole blood analysis enables assessment of immune cell types that are less amenable to freeze and thaw, the cryopreserved PBMCs were thawed and cultured in batch, with samples selected to ensure age and sex balance between patients with PD and NCs, serving to both limit interassay variability and minimize batch effects. ${ }^{20}$

\section{Flow Cytometry}

Multiple multiparametric flow cytometry antibody panels were developed to comprehensively characterize phenotypic and functional immune profiles of human peripheral immune cell subsets previously identified as proinflammatory or regulatory in the context of CNS-directed and other immune- 
mediated conditions, as we have previously reported. ${ }^{20-24}$ eTable 3 lists the antibodies used for characterizing the phenotypes and functional response profiles of immune cells in both fresh whole blood and in cryopreserved PBMCs. For whole blood immune cell staining, $2 \mathrm{~mL}$ of peripheral blood was lyzed with equal volume of $1 \mathrm{X}$ RBC lysis buffer (BioLegend). For PBMC staining, thawed cells were stained with Aqua (Thermo Fisher) to exclude dead/dying cells during analysis. Cells were incubated with surface antibody cocktails for 30 minutes at room temperature. After 2 washes, samples were fixed with Cytofix/Cytoperm buffer (BD Biosciences) at $4^{\circ} \mathrm{C}$ and then resuspended in PBS before acquisition by flow cytometry. For transcriptional factor staining, surface staining was followed by fixing cells with TF fixation and permeabilization buffer for 45 minutes (Thermo Fisher) and resuspending in the TF washing buffer (Thermo Fisher) overnight before incubation with TF antibody cocktail for 1 hour on the next day. For staining of cytokines from different immune cells, cells were first treated with PMA $(20 \mathrm{ng} / \mathrm{mL}$, Sigma-Aldrich), ionomycin (500 ng/mL, Sigma-Aldrich) and GolgiStop (Monensin, BD Biosciences) (B cell and T cell), or LPS (100 ng/mL, Sigma-Aldrich) and GolgiStop for 4 hours. After live/dead staining and surface staining, cells were fixed/ permeabilized with Cytofix/Cytoperm buffer (BD Biosciences) and then resuspended in ICS buffer overnight (BD Biosciences). Intracellular cytokine staining was performed the next day. All flow cytometry was performed by a single operator who was blinded to the sample source and followed the same standardized protocols for acquisition and analysis. Samples were acquired by an LSRFortessa flow cytometer (BD Biosciences) stringently maintained by the flow cytometry core facility at the University of Pennsylvania. The raw data were further analyzed by FlowJo software analysis (BD Biosciences).

\section{Calculation of Absolute Cell Count for Each Immune Cell Subsets Using Cryopreserved PBMCs}

To estimate absolute counts in the absence of formal clinical laboratory testing, we first used fresh whole blood aliquots from the same samples to measure lymphocyte (CD45 $\left.{ }^{\text {high }} \mathrm{SSC}^{\text {low }}\right)$, monocyte $\left(\mathrm{CD} 45^{\text {int }} \mathrm{SSC}^{\text {int }}\right)$, and granulocyte (CD $\left.45^{\text {low }} \mathrm{SSC}^{\text {high }}\right)$ counts, calculated as percentage of each population multiplied by the total white blood cell count. We could then estimate the counts of immune cell subsets within the PBMCs based on their percentages within the PBMCs, multiplied by either the lymphocyte count (for lymphocyte subsets) or the monocyte count (for monocyte subsets).

\section{Statistical Analysis}

Nonparametric Mann-Whitney 2-tailed testing was used for statistical comparisons between 2 groups with adjustment for multiple comparisons using the Benjamini-Hochberg procedure $t$ controlling for a false discovery rate $<0.05$ for each of the discovery and validation cohorts, separately. Linear regression modeling was used to test the correlation between different immune cell subsets. GraphPad Prism 9 was used to perform all the statistical analyses including ROC (Wilson/ Brown Method) and PCA analysis. Data are represented using individual dots for each participant. $p$ Values of 0.05 or less were considered statistically significant.

\section{Data Availability}

Anonymized data will be shared by request from any qualified investigator.

\section{Results}

\section{Immunophenotyping Major Immune Cell Subsets in Whole Blood of Patients With PD and Neurologically Normal Controls}

To broadly characterize the major circulating immune cell types of patients with PD and neurologically NCs we established a 15-color flow cytometry panel to immune phenotype in fresh whole blood: neutrophils $\left(\mathrm{CD} 15^{+} \mathrm{CD} 16^{+}\right)$, eosinophils $\left(\right.$ Siglec- $\left.8^{+}\right)$, basophils $\left(\mathrm{CD} 123^{\text {high }}\right)$, monocytes $\left(\mathrm{CD} 14^{+}\right)$, dendritic cells $\left(\mathrm{Lin}^{-} \mathrm{HLA}-\mathrm{DR}^{+}\right)$, NK cells (CD14-, $\left.\mathrm{CD} 16^{+}\right)$, $\mathrm{T}$ cells $\left(\mathrm{CD}^{+}\right)$, and $\mathrm{B}$ cells $\left(\mathrm{CD} 19^{+}\right)$, with the antibody panel and gating strategy summarized in eTable 4 and eFigure 1, respectively. Analysis of the (UPA) discovery cohort (eTables 1 and 2) suggested that absolute B-cell counts were decreased in the blood of patients with PD compared with NCs (Figure 1A), with no apparent differences in other major cell types including granulocytes, myeloid cells, NK cells, and $\mathrm{T}$ cells. This observation was confirmed in an independent (Columbia University) validation cohort (eTable 1 and eTable 2, links.lww.com/NXI/A676; Figure 1B), pointing to an abnormal B-cell immune compartment in patients with PD.

\section{Comprehensive Immunophenotyping Within the B-Cell Compartment Reveals a Preferential Decrease of Transitional B-Cell Populations}

To analyze distinct subsets more comprehensively within the B-cell compartment in patients with PD, we next developed and applied 3 15-color multiparametric flow cytometry panels to cryopreserved PBMCs isolated from patients and controls. These panels captured both phenotypic and functional profiles of B-cell subsets (eTable 4; eFigure 2A, links.lww.com/ NXI/A676), including quantification of activation and proliferation markers, molecules associated with antigenpresenting function, and known B-cell cytokines previously implicated in immune activation (e.g., TNF $\alpha$, IL-6, and GMCSF) and immune regulation (e.g., IL-10). Interpretation of the PBMC analyses and validity of comparisons across groups were optimized by applying strict standard operating procedures $^{20}$ and routinely confirming high cell viabilities (eFigure $2 \mathrm{~B}$ ). We observed that among B-cell subsets (eFigure 3), immature transitional B cells (including T1, T2, and T3 transitional B cells) were disproportionally decreased in patients with PD (Figure 2, A-F), resulting in substantial decreases of the ratios of transitional/mature $\mathrm{B}$ cells (Figure $2 \mathrm{E}$ ). Within mature $\mathrm{B}$ cells, the numbers of $\mathrm{CD}_{2} 7^{-} \mathrm{IgD}^{-}$memory $\mathrm{B}$ cells (also known as double-negative memory $\mathrm{B}$ cells previously implicated in 
Figure 1 Whole Blood Immunophenotyping of Major Peripheral Immune Cell Types in Patients With PD and Neurologically Normal Controls

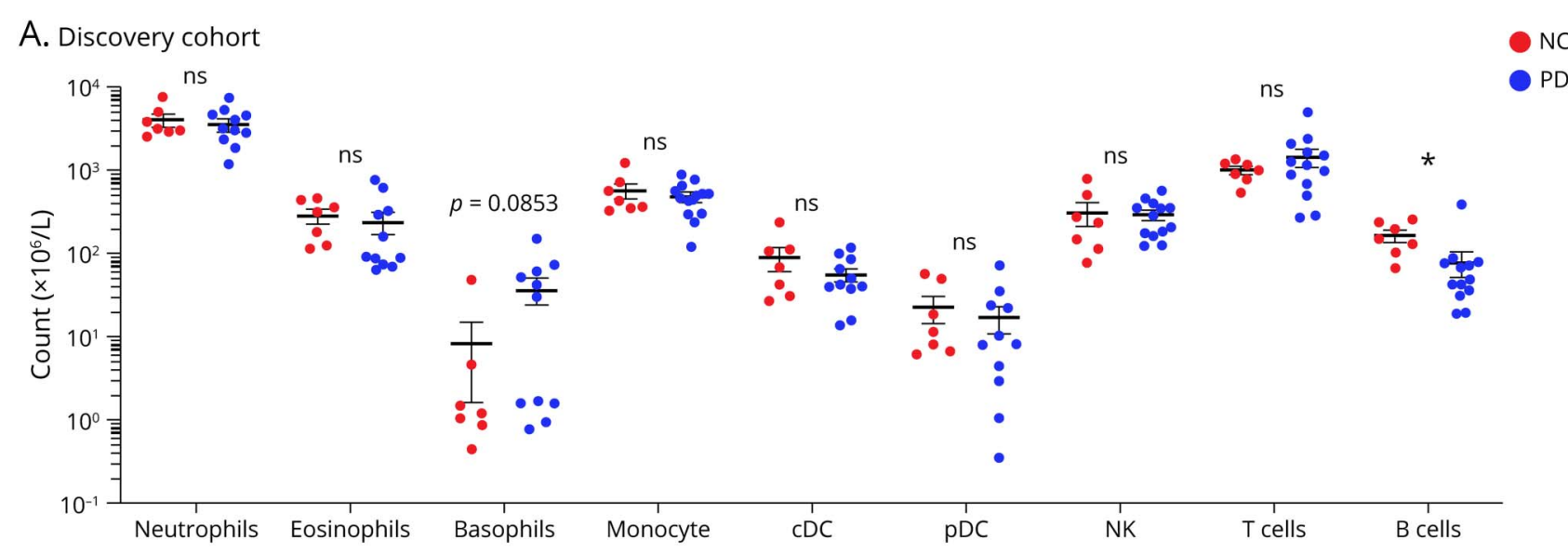

B. Validation cohort

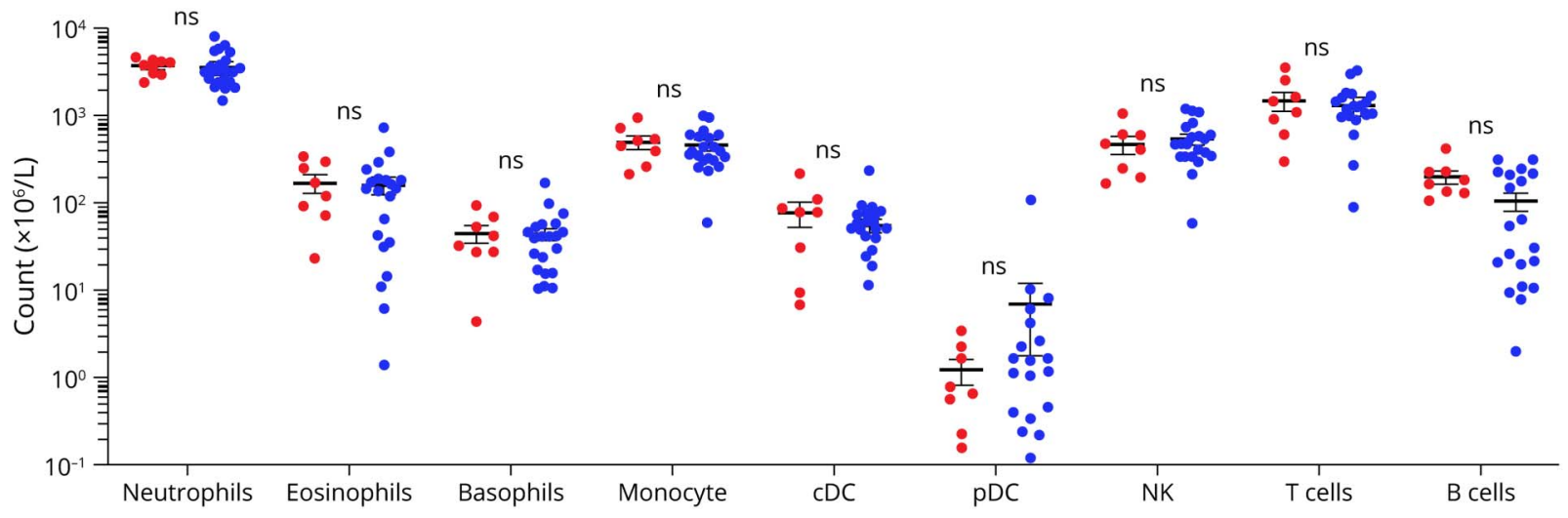

Whole blood samples were collected from 2 independent cohorts of patients with well-characterized Parkinson disease (PD) and normal controls (NCs). Fresh samples underwent red blood cell lysis and immediately stained with the indicated panel of antibodies to capture major immune cell types including neutrophils, eosinophils, basophils, monocytes, dendritic cells, NK cells, T cells, and B cells. (A) Absolute counts of circulating B cells are decreased in patients with PD relative to NCs in the discovery (UPA) cohort (comprising $\left.\mathrm{n}_{(\mathrm{NC})}=7, \mathrm{n}_{(\mathrm{PD})}=13\right)$ and $(\mathrm{B})$ confirmed in the validation $\left(\right.$ Columbia) cohort $\left(\mathrm{n}_{(\mathrm{NC})}=8, \mathrm{n}_{(\mathrm{PD})}=21\right)$. $\mathrm{ns}=\mathrm{not}_{\mathrm{significant}}{ }^{*} p<0.05$.

autoimmune and infectious disease $\mathrm{e}^{25-27}$ ) were decreased in patients with PD (Figure $2 \mathrm{G}$ ), whereas no appreciable abnormalities were noted for other B-cell subsets (Figure $2 \mathrm{G}$ ).

\section{Altered Functional Responses of B Cells in Patients With PD}

We next assessed functional markers of B-cell activation (Figure 3A), proliferation (figure 3, B and C), and expression of costimulatory molecules including CD80 and CD86 (Figure 3D), used by $\mathrm{B}$ cells to interact with and activate $\mathrm{T}$ cells as part of their antigen-presenting cell (APC) capacity. We observed decreases in proliferating $\left(\mathrm{Ki}-67^{+}\right)$B-cell counts in patients with PD compared with controls in both discovery and validation cohorts (Figure 3B). The degree of decrease in $\mathrm{Ki}-67^{+} \mathrm{B}$ cell counts positively correlated with the degree of decrease in the total B-cell counts in all groups (Figure 3C). Also decreased in the circulation of patients with PD were 2 B-cell subsets known for their efficient APC capacities,

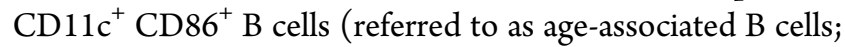
Figure $3 \mathrm{E}$ ), and $\mathrm{CD} 43^{+} \mathrm{CD} 27^{+} \mathrm{B}$ cells (referred to as B1 cells; Figure $3 \mathrm{~F})$. Because $\mathrm{B}$ cells can regulate local immune responses through expression of distinct cytokine combinations (and particularly the balance between proinflammatory and anti-inflammatory cytokines, ${ }^{15,28-37}$ we next used intracellular cytokine staining to examine cytokine expression profiles of B cells. We observed that patients with $\mathrm{PD}$, in both the discovery and validation cohorts, harbored decreased counts but not frequencies of IL-10-producing (antiinflammatory) B cells compared with NC (Figure 4A). Frequencies, but not the counts, of both GM-CSF and TNFa expressing (proinflammatory) B cells were increased in the patients with PD (Figure 4B), which was reflected in significant increases in the GM-CSF/IL-10 and TNFa/IL-10 cytokine expression ratios of the PD patient B cells (Figure 4, C and D).

\section{Immune Profiling of Innate Immune Cells and T Cells Reveals a Reduction of Follicular T Cells in Patients With PD}

Given the growing recognition of the importance of interactions between subsets of B cells, $T$ cells, and innate cells, we next considered whether the B-cell abnormalities we observed 

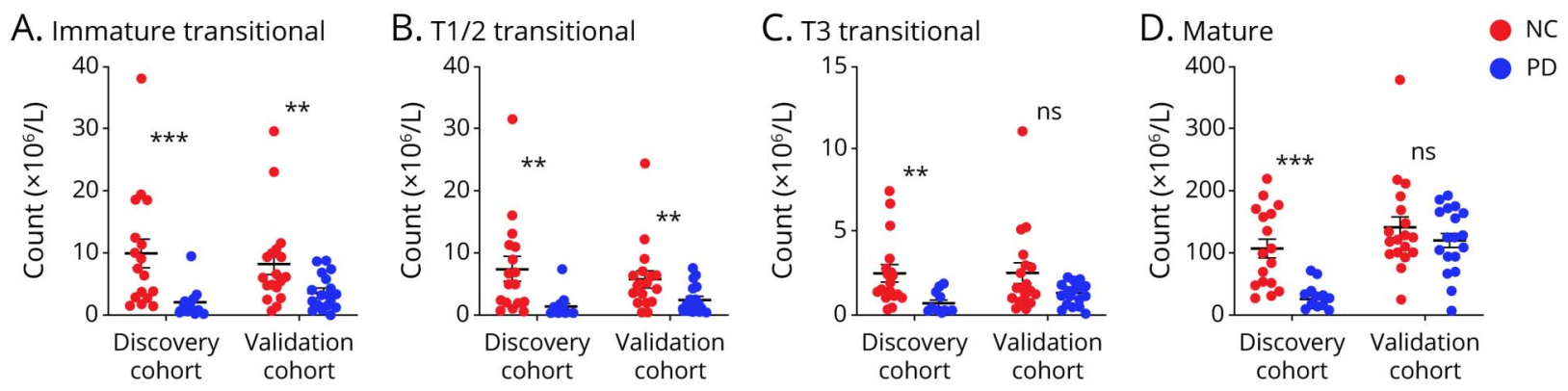

E. Ratio (transitional/mature)
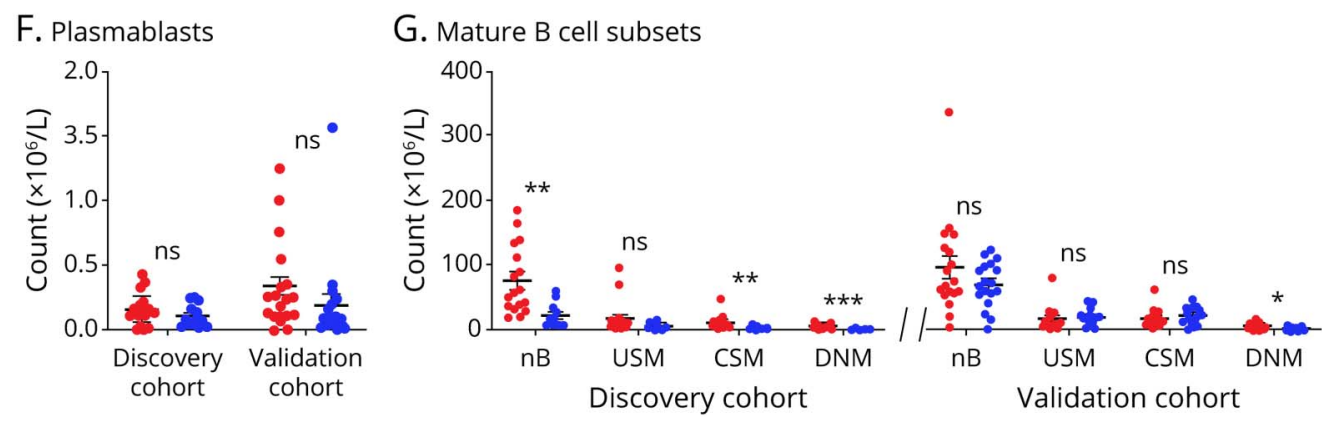

Cryopreserved peripheral blood mononuclear cells were thawed and stained with B cell-related markers. (A-G) Among all B-cell subsets, transitional B cells are particularly affected in patients with Parkinson disease $(P D)(A-C)$ resulting in reduced ratios of their transitional to mature $B$ cells $(E)$. ns $=$ not significant, ${ }^{*} p<0.05,{ }^{*} p<0.01$, and $* * * p<0.001$. Discovery cohort (comprising $\left.\mathrm{n}_{(\mathrm{NC})}=12, \mathrm{n}_{(\mathrm{PD})}=17\right)$ and validation cohort $\left(\mathrm{n}_{(\mathrm{NC})}=18, \mathrm{n}_{(\mathrm{PD})}=18\right)$. NC $=$ normal control.

in patients with PD (including diminished proliferation, decreased transitional B-cell counts, and the proinflammatory cytokine profile shift) could be understood on the basis of changes in potentially interacting non-B cells. To this end, we developed a series of multiparametric flow cytometry panels to capture the functional phenotypes of $\mathrm{T}$ cells and myeloid cells (eFigure 4, links.lww.com/NXI/A676). Similar to $\mathrm{B}$ cells, $\mathrm{Ki}-67^{+}$(proliferating) $\mathrm{CD} 4^{+} \mathrm{T}$ cells counts were also reduced in patients (Figure 5A). We further found that the numbers of lymphoid-tissue homing central memory (TCM) $\mathrm{CD}^{+} \mathrm{T}$ cells (but not effector memory $\mathrm{T}$-cell subsets) are decreased in the patients with PD (Figure 5B). In particular, levels of $\mathrm{CD}^{+}$follicular $\mathrm{T}$ cells (Tfh, $\mathrm{CXCR}^{+} \mathrm{CD} 4 \mathrm{RA} \mathrm{R}^{-}$) and especially the $\mathrm{ICOS}^{+} \mathrm{PD}-1+\mathrm{T}$ fh subset known to interact with $B$ cells to help them form and maintain germinal centers were significantly reduced in patients with PD compared with NCs (Figure 5, C and D). Absolute counts of the Tfh cells correlated with the Ki-67 $7^{+}$B-cell counts (Figures 5, E and F) consistent with the possibility that decreased numbers of Tfh cell and hence decreased Tfh:B cell interactions may account for the observed decreases in transitional B cells of patients with PD.

\section{Unique Signature of the B- and T-Cell Compartments Characterizes Patients With PD Compared With Neurologically Normal Controls}

To follow-up on our directed analyses of immune cell subsets previously implicated in inflammatory CNS conditions, we next performed an exploratory data-driven principal component analysis (PCA) on the full data set (198 features in total, comprising both immune cell counts and frequencies) across all 65 individuals. As shown in Figure 6A, the first 10 principal components accounted for $65.5 \%$ of the total variance, with principal component 1 (PC1) explaining $16.5 \%$ and $\mathrm{PC} 2$ explaining 11.7\% (Figure 6B). Notably, PD and NC samples separated well along PC2 (Figure 6B) regardless of the cohorts (Figure 6C). ROC curve application to $\mathrm{PC} 2$ values indicated an area under the curve (AUC) of 0.88 , with $p$ value $<0.0001$ suggesting that PC2 showed good ability to discriminate PD from NC (Figure 6D). This separation was not driven by age or sex (data not shown). Among the top 30 immune markers within the PC2 loadings, 6 belonged to the set of markers that define B-cell populations, whereas 7 belonged to the set of markers that define Tfh cells (Figure 6E). Increased expression of TNFa and GMCSF by both $\mathrm{B}$ cells and by $\mathrm{CD} 4^{+}$and $\mathrm{CD} 8^{+} \mathrm{T}$ cells (Figures 6 , $\mathrm{F}-\mathrm{G}$ ) contributed to the immune signature enriched in patients with PD compared with NCs.

\section{Discussion}

In the current study, we interrogated the phenotypic and functional profiles of peripheral immune cells in 2 independent (discovery and validation) cohorts of patients with $\mathrm{PD}$ and matched neurologically normal controls. We demonstrate decreased total B-cell counts (driven by decreases in immature/transitional B-cell subsets), as well as diminished B-cell proliferation, in the circulation of patients with PD. Decreased Tfh counts in the patients with PD were associated 


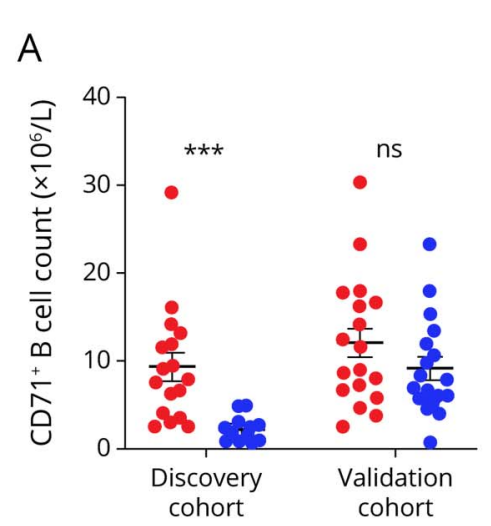

$\mathrm{D}$

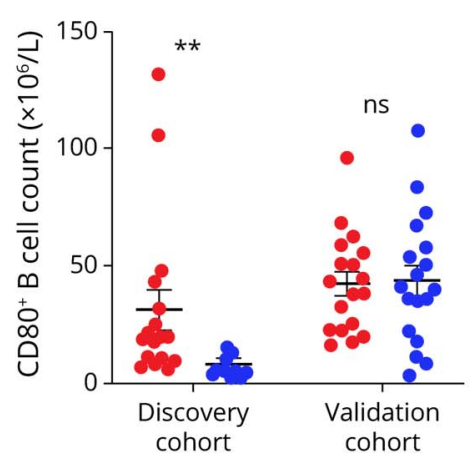

\section{B}

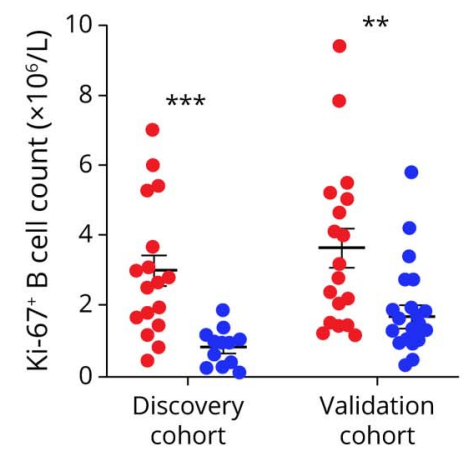

$\mathrm{E}$

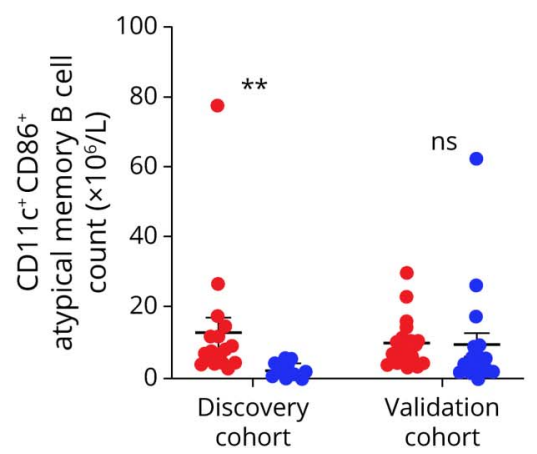

C
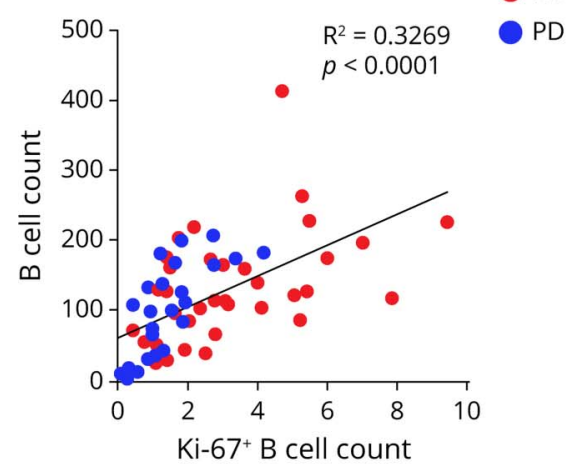

F

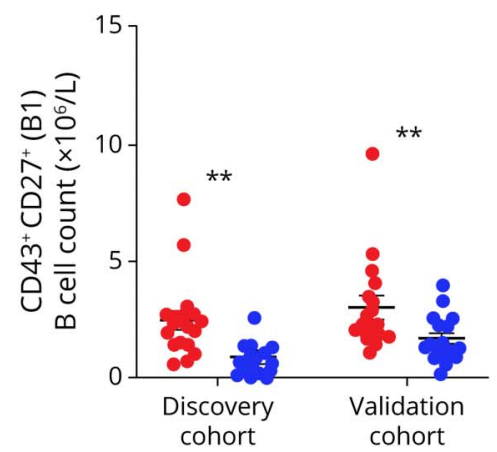

Cryopreserved peripheral blood mononuclear cells were thawed and stained with B cell-related markers to capture their activation/proliferation states and their costimulation capacity. Although the activation marker CD71 did not show consistent changes in the 2 cohorts (A), patients with Parkinson disease (PD) harbor decreased counts of circulating B cells expressing the proliferation-associated marker Ki-67 (B), and the decreased proliferation correlates with their decreased B-cell counts (C). A decrease in CD80+B cells was only observed in the discovery cohort but not in the validation cohort (D). Levels of both CD11 $C^{+}$ CD86 ${ }^{+}$atypical memory B cells (E) and CD43 ${ }^{+} \mathrm{CD} 27^{+}$B1 cells (F) are decreased in the circulation of patients with PD. ns $=$not significant, ${ }^{*} p<0.05,{ }^{* \star} p<0.01$, and $* \star \star x p<0.001$. Discovery cohort (comprising $\left.\mathrm{n}_{(\mathrm{NC})}=12, \mathrm{n}_{(\mathrm{PD})}=17\right)$ and validation cohort $\left(\mathrm{n}_{(\mathrm{NC})}=18, \mathrm{n}_{(\mathrm{PD})}=18\right)$. $\mathrm{NC}=$ normal control.

with their decreased B-cell counts. We also observed a shift toward a more proinflammatory cytokine response profile in both $\mathrm{B}$ cells and $\mathrm{T}$ cells of patients with PD. Together, these data reveal previously unexpected abnormalities in the B-cell compartment of patients with PD and implicate aberrant B-cell:T-cell interactions in their dysregulated immune state.

B cells have traditionally been considered based on their contributions to humoral immune responses, through their potential to generate antigen specific protective antibodies (or, in the context of autoimmune diseases, auto-antibodies that recognize self-antigens). ${ }^{15}$ Deposition of IgG1 antibodies has been described in the substantia nigra (SN) of PD patients, which may be associated with local microglial activation. ${ }^{7}$ More recent studies identified that $\alpha$-synuclein-specific autoantibodies are increased in the peripheral blood and CSF of patients with PD compared with controls. ${ }^{38-40}$ Although these findings were taken to suggest a pathologic role of antibodies in PD, a more recent study by Li et al. ${ }^{41}$ reported that naturally occurring antibodies against $\alpha$-synuclein may be disease protective because they may neutralize the seeding of intracellular synuclein aggregates. These studies highlight the potentially complex ways in which antibody-related B-cell responses may participate in PD disease pathogenesis.
In addition to generating antibodies, it is now well known in other fields of immunology that B cells are actively involved in regulating local immune responses through multiple antibody-independent cellular functions, ${ }^{36}$ such as antigen presentation to $\mathrm{T}$ cells ${ }^{42,43}$ and via secretion of either pro- or anti-inflammatory cytokines that can modulate the activation of other immune cells, including T-cell subsets and innate cells. ${ }^{14,32,44}$ Our findings indicate that patients with PD have preferential decreases in numbers of circulating antiinflammatory B-cell subsets (including transitional B cells and IL-10-producing B cells), which is consistent with previous work by Alvarez-Luquin et al. ${ }^{45}$ showing that $\mathrm{CD} 24^{\text {high }}$ $\mathrm{CD} 38^{\text {high }} \mathrm{IL}-10^{+} \mathrm{B}$ cells are decreased in untreated patients with PD. We further observed that proinflammatory cytokine $\left(\mathrm{GM}_{-} \mathrm{CSF}^{+}\right.$and $\left.\mathrm{TNF}^{+}\right)$responses of $\mathrm{B}$ cells are increased in patients with $\mathrm{PD}$, reflecting a shift in the balance of their cytokine-defined B-cell subsets. These findings extend prior work $^{46-48}$ and indicate that antibody-independent functions of $\mathrm{B}$ cells may also be involved in PD pathogenesis. Indeed, transitional B cells and IL-10-producing B cells are well recognized in the field of autoimmunity as important checkpoint regulators of autoreactive $\mathrm{T}$ cells, ${ }^{34}$ whereas proinflammatory cytokine-expressing $\mathrm{B}$ cells have been shown to contribute to aberrant responses of $\mathrm{T}$ cells (including Th17 cells) and 

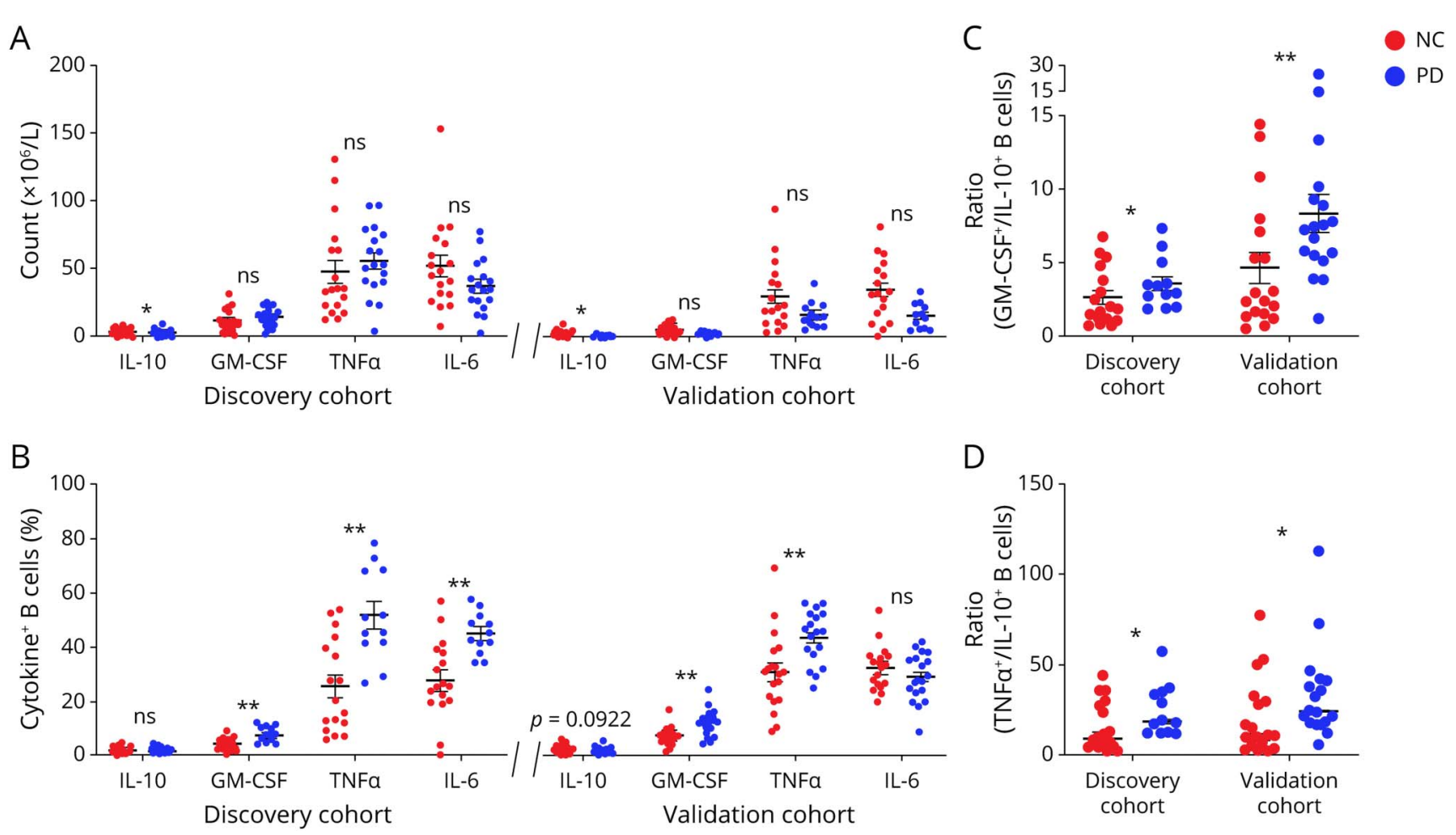

Cryopreserved peripheral blood mononuclear cells were thawed and rested overnight before stimulation with PMA and ionomycin in the presence of GolgiStop for 4 hours. B-cell expression of IL-10, GM-CSF, TNFa, and IL-6 was detected by flow cytometry using intracellular cytokine staining. IL-10-producing B-cell counts are reduced in patients with Parkinson disease (PD) (A), whereas GM-CSF and TNFa-expressing B-cell frequencies are increased in patients with PD (B), which together results in decreases of both GM-CSF/IL-10 ratios (C) and TNFa/IL-10 ratios (D) ratios of cytokine-expressing B cells in PD compared with normal control (NC). $\mathrm{ns}=$ not significant, $* p<0.05$, and $* * p<0.01$. Discovery cohort (comprising $\left.\mathrm{n}_{(\mathrm{NC})}=12, \mathrm{n}_{(\mathrm{PD})}=17\right)$ and validation cohort $\left(\mathrm{n}_{(\mathrm{NC})}=18, \mathrm{n}_{(\mathrm{PD})}=18\right)$.

innate cells in traditionally considered $\mathrm{T}$ cell-mediated diseases. ${ }^{29,31,33,49,50}$ Although our study did not assess antigenspecific responses, it is interesting to speculate that the B-cell abnormalities we discovered in patients with PD may be linked with previously reported abnormalities in the T-cell compartment of patients, including observations of abnormally increased Th17 and $\alpha$-synuclein-reactive T cells. ${ }^{9-11}$

In contrast to a prior study ${ }^{48}$ that suggested increased proportions of circulating Tfh cells in patients with PD, we observed decreased absolute counts of Tfh cells in patients with PD compared with controls in both our discovery and validation cohorts and further noted that the reduced Tfh cell numbers in patients correlated with their diminished B-cell counts. Crosstalk between Tfh cells and B cells is known to be important for proper function of both cell types, ${ }^{35,51}$ and we speculate that decreased $\mathrm{Tfh}$ cells in patients may underlie their diminished B-cell proliferation also resulting in preferentially lesser generation of transitional/regulatory B cells. In keeping with this, IL-21 (produced by Tfh cells) is known to be particularly important for the generation of IL-10producing regulatory $\mathrm{B}$ cells. ${ }^{30}$

There are several potential limitations to our study. From a technical perspective, the use of cryopreserved PBMCs has the important advantage of reducing interassay variability and batch effects, although the freeze/thaw of PBMCs may impact cell yields and viability and unevenly influence different immune cell subsets. We cannot exclude an impact of such influences on our results, although the strict SOPs applied consistently across all sample likely contributed to the reassuringly high yields and viabilities of our samples, and we have no reason to suspect that any processing artifact would systematically affect the PD patient samples differently than the control samples. From a study design standpoint, although the independent discovery and validation cohorts enable us to ascertain PD immune abnormalities more confidently, our study is cross-sectional, thus capturing only a snapshot of PD patients' immune status and limiting our ability to relate our findings to the course and outcome of patients. Future studies that serially assess immune profiles in patients may provide additional insights into the sequence and dynamics of immune cell subset interactions involved in the disease. Interpreting the immunologic differences that we observed between patients with PD and controls might be confounded by medications used to treat PD. In particular, immune cells can both secrete and respond to dopamine, ${ }^{52-58}$ and the effects of dopamine can be complex as it has been shown to either enhance or limit responses of both B cells and $\mathrm{T}$ cells (which may depend in part on the dopamine receptor 
Figure 5 Decreased Counts of Follicular T Cells Correlate With Decreased Counts of Ki- $67^{+}$B Cells in Patients With Parkinson Disease

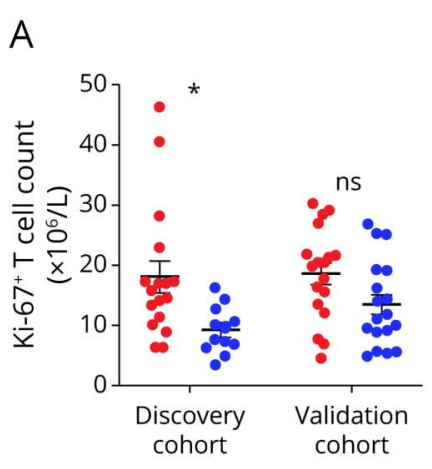

C

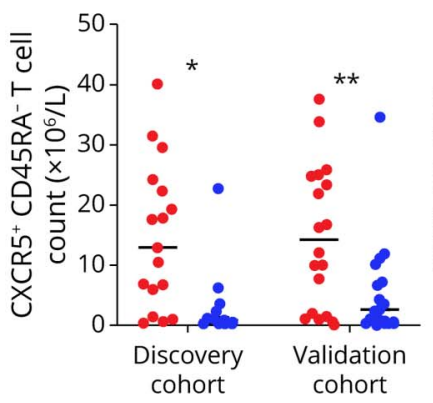

$\mathrm{B}$

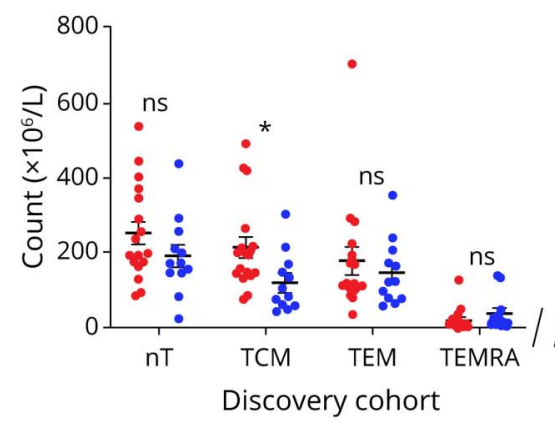

$\mathrm{E}$

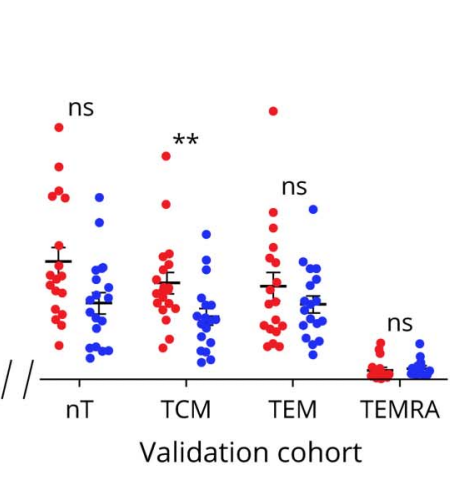

$\mathrm{F}$

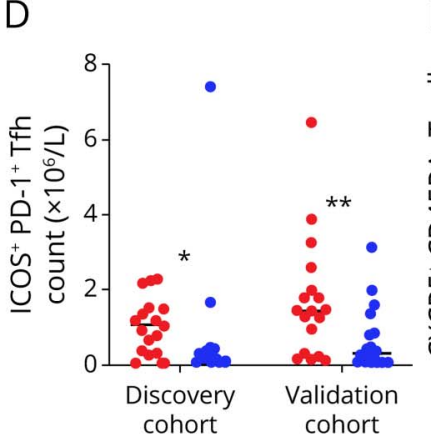

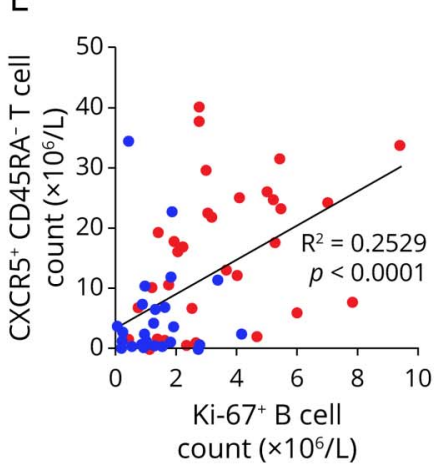

F

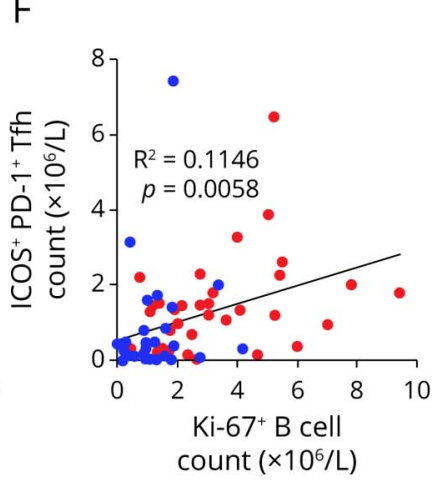

(A-D) Cryopreserved peripheral blood mononuclear cells were thawed and stained with panels of T cell-related phenotypic and functional markers (eTable 4 and Figure 6) and then analyzed by flow cytometry in the discovery cohorts and validation cohorts of patients with Parkinson disease (PD) and normal controls (NCs). (A) Proliferating T cells (Ki-67+ T cells) are reduced in patients with PD. (B) Within major T-cell subsets, counts of central memory T cells are decreased in patients with PD. (C and D) Decreased counts of follicular T (Tfh) cells are seen in patients with PD, and these reduced Tfh cell counts correlate with the decreased Ki-67-expressing B cells (E and F). ns = not significant, ${ }^{*} p<0.05$ and $* * p<0.01$. Discovery cohort (comprising $\left.n(N C)=12, \mathrm{n}(\mathrm{PD})=17\right)$ and validation cohort $(\mathrm{n}(\mathrm{NC})=18, \mathrm{n}(\mathrm{PD})=18)$.

profiles and the context of exposure, such as the immune cell state of activation). For example, dopamine can inhibit T-cell activation through its $\mathrm{D} 1$ and $\mathrm{D} 2$ receptors, ${ }^{55}$ whereas it may favor proinflammatory Th1 and Th17 T-cell responses when signaling through its D3 and D5 receptors. ${ }^{59-61}$ Dopamine can also preferentially induce apoptosis of cycling B cells, but not of resting $B$ cells, ${ }^{62}$ and when released from The cells can strengthen T-B synapse within germinal centers, thereby boosting B-cell responses. ${ }^{54}$ To gauge the possible impact of dopamine, we obtained LEDD (L-dopa equivalent daily dose) scores (eTable 2, links.lww.com/NXI/A676), considered by some authors to provide an estimation of a patient's daily medication exposure. ${ }^{63}$ We found no apparent relationship between LEDD scores and PD-associated immune abnormalities, though we cannot entirely exclude effects of PD medications on our findings. Other (nonPD) medications were common in both our participants with PD and NCs, who also harbored a range of comorbidities. Although these other medications and comorbidities may also impact immune measures, they did not appear imbalanced between the participants with PD and NCs in either the discovery or validation cohorts. Finally, although our findings provide intriguing insights into a dysregulated peripheral immune compartment in patients with $\mathrm{PD}$, how such dysregulation relates to disease-relevant processes within the CNS remains to be elucidated. In this regard, future studies interrogating immune cells in the CSF and/or within the CNS parenchyma of patients will be of interest.

In summary, our study uncovers a novel B-cell signature in PD and suggests that aberrant interactions between $\mathrm{T}$ cells and antibody-independent functions of B cells may be involved in PD pathogenesis. Further investigation of the significance of such interactions in PD is warranted. If confirmed to be pathogenic, there may be potential to therapeutically target B-cell:T-cell interactions in PD, an approach increasingly applied across a growing range of human immune-mediated (including neurologic) conditions.

\section{Study Funding}

This work is supported by iAward (Innovation Award) from partnership grant between University of Pennsylvania and Sanofi, RO1-NS115139, U19-AG062418. The Columbia University cohort collection was supported by the Parkinson's Foundation.

\section{Disclosure}

R. Li, L.R. Baratta, L. Zuroff, M.E. Diaz-Ortiz, B. Zhang, K. Shinoda, A. Rezk, R.N. Alcalay, and A. Chen-Plotkin report no 
Figure 6 Identification of the Immune Signature of Peripheral Immune Cells in Patients With Parkinson Disease Using Unbiased PC Analysis

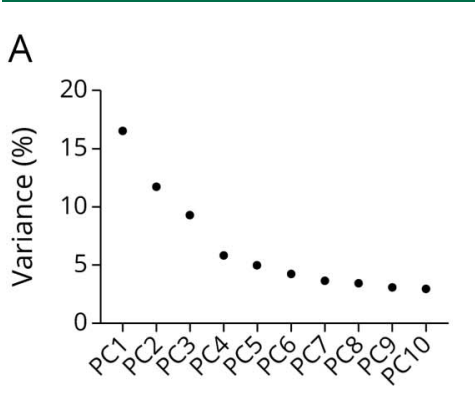

E

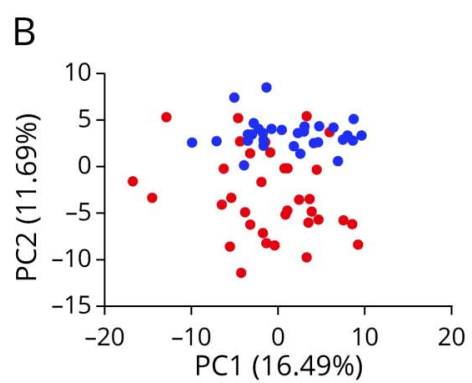

$\longrightarrow$ Follicular T cell signature
$\leftarrow$ TNFa/GM-CSF signature

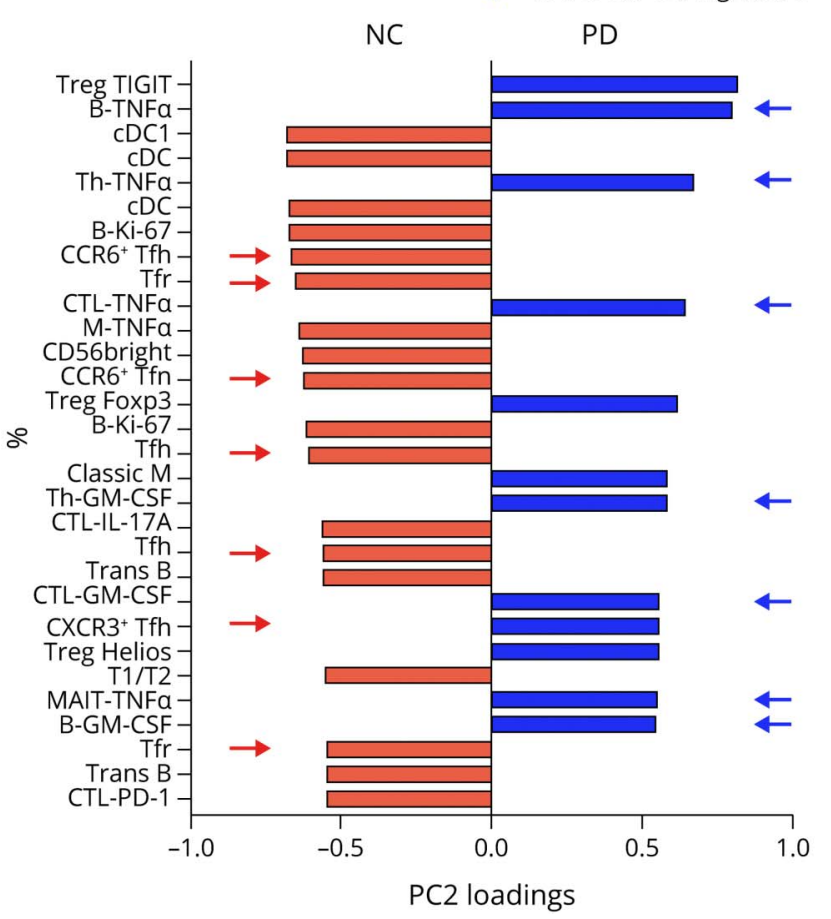

C

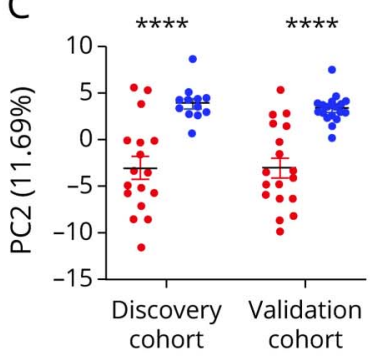

D. PC2 values

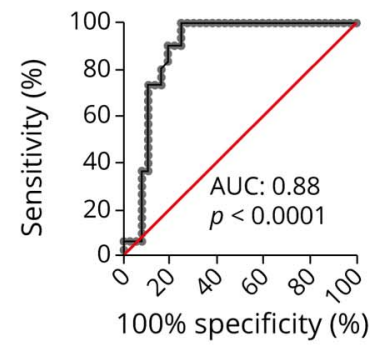

$\mathrm{F}$

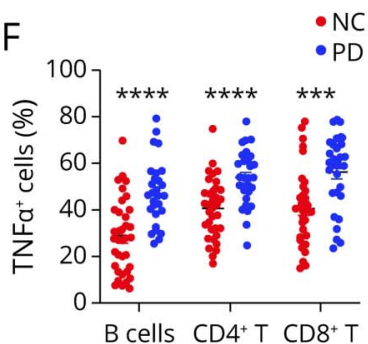

NC

$\mathrm{PD}$

G

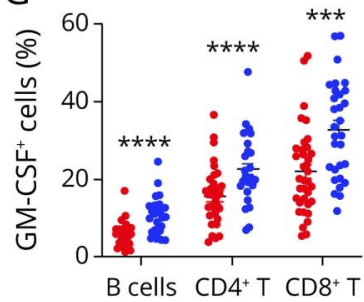

Principal component (PC) analysis was applied to the complete data set containing 198 features comprising both counts and frequencies of different immune cell subset/functional markers. (A) Percent variance accounted for by each of the first 10 principal components. (B) Plot of PC1 vs PC2 showing separation between Parkinson disease (PD) and normal control (NC) along PC2. (C) Boxplot of PC2 values grouped by disease status and cohort. (D) ROC curve of PC2 values (area under the curve (AUC): 0.88, $p<0.0001$ ). (E) Top 30 features within the PC2 loadings. (F and G) TNFa and GM-CSF expressing B-cell and T-cell

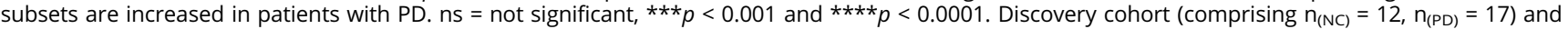
validation cohort $\left(\mathrm{n}_{(\mathrm{NC})}=18, \mathrm{n}_{(\mathrm{PD})}=18\right)$.

disclosures relevant to the manuscript. T. Tropea reports grants from iAward (Innovation Award), a partnership grant between University of Pennsylvania and Sanofi, during the conduct of the study, and personal fees from Sanofi Genzyme, outside the submitted work. A. Bar-Or has participated as a speaker in meetings sponsored by and received consulting fees and/or grant support from Accure, Atara Biotherapeutics, Biogen, BMS/Celgene/Receptos, GlaxoSmithKline, Gossamer, Janssen/Actelion, MedImmune, Merck/EMD Serono, Novartis, Roche/Genentech, and Sanofi Genzyme. Go to Neurology.org/NN for full disclosures.

\section{Publication History}

Received by Neurology: Neuroimmunology \& Neuroinflammation June 4, 2021. Accepted in final form November 9, 2021.
Appendix Authors

\begin{tabular}{|c|c|c|}
\hline Name & Location & Contribution \\
\hline $\begin{array}{l}\text { Rui Li, MD, } \\
\text { PhD }\end{array}$ & $\begin{array}{l}\text { The Center for } \\
\text { Neuroinflammation and } \\
\text { Neurotherapeutics and the } \\
\text { Department of Neurology, } \\
\text { Perelman School of Medicine, } \\
\text { University of Pennsylvania, } \\
\text { Philadelphia, PA }\end{array}$ & $\begin{array}{l}\text { Drafting/revision of the } \\
\text { manuscript for content, } \\
\text { including medical writing for } \\
\text { content; major role in the } \\
\text { acquisition of data; study } \\
\text { concept or design; and } \\
\text { analysis or interpretation of } \\
\text { data }\end{array}$ \\
\hline $\begin{array}{l}\text { Thomas } \\
\text { Francis } \\
\text { Tropea, } \\
\text { DO }\end{array}$ & $\begin{array}{l}\text { Department of Neurology, } \\
\text { Perelman School of Medicine, } \\
\text { University of Pennsylvania, } \\
\text { Philadelphia, PA }\end{array}$ & $\begin{array}{l}\text { Drafting/revision of the } \\
\text { manuscript for content, } \\
\text { including medical writing for } \\
\text { content; study concept or } \\
\text { design; and analysis or } \\
\text { interpretation of data }\end{array}$ \\
\hline
\end{tabular}

Continued 
Appendix (continued)

\begin{tabular}{lll}
\hline Name & Location & Contribution \\
\hline $\begin{array}{l}\text { Laura } \\
\text { Rosa } \\
\text { Baratta, } \\
\text { BSc }\end{array}$ & $\begin{array}{l}\text { Department of Neurology, } \\
\text { Perelman School of Medicine, } \\
\text { University of Pennsylvania, } \\
\text { Philadelphia, PA }\end{array}$ & $\begin{array}{l}\text { Drafting/revision of the } \\
\text { manuscript for content, } \\
\text { including medical writing for } \\
\text { content }\end{array}$ \\
\hline $\begin{array}{l}\text { Leah } \\
\text { Zuroff, } \\
\text { MD, MS }\end{array}$ & $\begin{array}{l}\text { The Center for } \\
\text { Neuroinflammation and }\end{array}$ & $\begin{array}{l}\text { Drafting/revision of the } \\
\text { manuscript for content, } \\
\text { including medical writing for } \\
\text { content }\end{array}$ \\
& $\begin{array}{l}\text { Department of Neurology, } \\
\text { Perelman School of Medicine, }\end{array}$ & \\
& $\begin{array}{l}\text { University of Pennsylvania, } \\
\text { Philadelphia, PA }\end{array}$ &
\end{tabular}

\section{Maria E. Department of Neurology, Drafting/revision of the}

Diaz-Ortiz, Perelman School of Medicine, manuscript for content, BSC University of Pennsylvania, including medical writing for Philadelphia, PADepartment content, and analysis or of Bioengineering, School of interpretation of data Engineering and Applied Sciences, University of Pennsylvania, Philadelphia, PA

Bo Zhang, Department of Cardiology,

M.D, PhD The fourth affiliated hospital of Harbin Medical University, Harbin, Heilongjiang, China

\begin{tabular}{lll}
\hline Koji & The Center for & $\begin{array}{l}\text { Drafting/revision of the } \\
\text { manuscript for content, } \\
\text { Shinoda, }\end{array}$ \\
MD, PhD & $\begin{array}{l}\text { Neuroinflammation and } \\
\text { Neurotherapeutics and the } \\
\text { Department of Neurology, } \\
\text { Perelman School of Medicine, } \\
\text { Content }\end{array}$ \\
& $\begin{array}{l}\text { University of Pennsylvania, } \\
\text { Philadelphia, PA }\end{array}$
\end{tabular}

\section{Ayman The Center for}

Rezk, PhD Neuroinflammation and Neurotherapeutics and the Department of Neurology, Perelman School of Medicin Philadelphia, PA

\begin{tabular}{ll}
\hline Roy N. & Department of Neurology, \\
Alcalay, & Columbia University, New \\
MD, MS & York, NY
\end{tabular}

Drafting/revision of the manuscript for content, including medical writing for content

\begin{tabular}{|c|c|c|}
\hline $\begin{array}{l}\text { Alice } \\
\text { Chen- } \\
\text { Plotkin, } \\
\text { MD }\end{array}$ & $\begin{array}{l}\text { Department of Neurology, } \\
\text { Perelman School of Medicine, } \\
\text { University of Pennsylvania, } \\
\text { Philadelphia, PA }\end{array}$ & $\begin{array}{l}\text { Drafting/revision of the } \\
\text { manuscript for content, } \\
\text { including medical writing for } \\
\text { content; study concept or } \\
\text { design; and analysis or } \\
\text { interpretation of data }\end{array}$ \\
\hline
\end{tabular}

\begin{tabular}{lll}
\hline Amit Bar- & The Center for & $\begin{array}{l}\text { Drafting/revision of the } \\
\text { Or, MD }\end{array}$ \\
& Neuroinflammation and & $\begin{array}{l}\text { meurotherapeutics and the } \\
\text { including medical writing for }\end{array}$ \\
& $\begin{array}{l}\text { Department of Neurology, } \\
\text { Perelman School of Medicine, }\end{array}$ & content; study concept or \\
University of Pennsylvania, & interpretation of data \\
& Philadelphia, PA &
\end{tabular}

\section{References}

1. GBDPsD Collaborators. Global, regional, and national burden of Parkinson's disease, 1990-2016: a systematic analysis for the global burden of disease study 2016. Lancet Neurol. 2018;17(11):939-953.

2. Shulman JM, De Jager PL, Feany MB. Parkinson's disease: genetics and pathogenesis. Annu Rev Pathol. 2011;6:193-222.

3. Kouli A, Torsney KM, Kuan WL. Parkinson's disease: etiology, neuropathology, and pathogenesis. In: Stoker TB, Greenland JC, eds. Parkinson's Disease: Pathogenesis and Clinical Aspects. AU; 2018.

4. Tan EK, Chao YX, West A, Chan LL, Poewe W, Jankovic J. Parkinson disease and the immune system - associations, mechanisms and therapeutics. Nat Rev Neurol. 2020; $16(6): 303-318$.
5. Chang D, Nalls MA, Hallgrimsdóttir IB, et al. A meta-analysis of genome-wide association studies identifies 17 new Parkinson's disease risk loci. Nat Genet. 2017; 49(10):1511-1516

6. Nalls MA, Blauwendraat C, Vallerga CL, et al. Identification of novel risk loci, causal insights, and heritable risk for Parkinson's disease: a meta-analysis of genome-wide association studies. Lancet Neurol. 2019;18(12):1091-1102.

7. Orr CF, Rowe DB, Mizuno Y, Mori H, Halliday GM. A possible role for humoral immunity in the pathogenesis of Parkinson's disease. Brain. 2005;128(Pt 11): 2665-2674.

8. Brochard V, Combadiere B, Prigent A, et al. Infiltration of CD4+ lymphocytes into the brain contributes to neurodegeneration in a mouse model of Parkinson disease. J Clin Invest. 2009;119(1):182-192.

9. Sulzer D, Alcalay RN, Garretti F, et al. T cells from patients with Parkinson's disease recognize alpha-synuclein peptides. Nature. 2017;546(7660):656-661.

10. Lindestam Arlehamn CS, Dhanwani R, Pham J, et al. alpha-Synuclein-specific T cell reactivity is associated with preclinical and early Parkinson's disease. Nat Commun. 2020;11(1):1875.

11. Sommer A, Marxreiter F, Krach F, et al. Th17 lymphocytes induce neuronal cell death in a human iPSC-based model of Parkinson's disease. Cell Stem Cell. 2018;23(1) 123-e6.

12. Kumar BV, Connors TJ, Farber DL. Human T cell development, localization, and function throughout life. Immunity. 2018;48(2):202-213.

13. Morell M, Varela N, Marañón C. Myeloid populations in systemic autoimmune diseases. Clin Rev Allergy Immunol. 2017;53(2):198-218.

14. Li R, Patterson KR, Bar-Or A. Reassessing B cell contributions in multiple sclerosis. Nat Immunol. 2018;19(7):696-707.

15. Martin F, Chan AC. Pathogenic roles of B cells in human autoimmunity; insights from the clinic. Immunity. 2004;20(5):517-527.

16. Barnas JL, Looney RJ, Anolik JH. B cell targeted therapies in autoimmune disease. Curr Opin Immunol. 2019;61:92-99.

17. Genovese MC, Kaine JL, Lowenstein MB, et al. Ocrelizumab, a humanized anti-CD20 monoclonal antibody, in the treatment of patients with rheumatoid arthritis: a phase I/II randomized, blinded, placebo-controlled, dose-ranging study. Arthritis Rheum. 2008;58(9):2652-2661.

18. Pescovitz MD, Greenbaum CJ, Krause-Steinrauf H, et al. Rituximab, B-lymphocyte depletion, and preservation of beta-cell function. N Engl J Med. 2009;361(22) 2143-2152.

19. Swanson CR, Berlyand Y, Xie SX, Alcalay RN, Chahine LM, Chen-Plotkin AS. Plasma apolipoprotein Al associates with age at onset and motor severity in early Parkinson's disease patients. Mov Disord. 2015;30(12):1648-1656.

20. Mexhitaj I, Nyirenda MH, Li R, et al. Abnormal effector and regulatory $\mathrm{T}$ cell subsets in paediatric-onset multiple sclerosis. Brain. 2019;142(3):617-632.

21. Ghadiri M, Rezk A, Li R, et al. Dimethyl fumarate-induced lymphopenia in MS due to differential T-cell subset apoptosis. Neurol Neuroimmunol Neuroinflamm. 2017;4(3): e340.

22. Ghadiri M, Fitz-Gerald L, Rezk A, et al. Reconstitution of the peripheral immune repertoire following withdrawal of fingolimod. Mult Scler. 2017;23(9):1225-1232.

23. Ghadiri M, Rezk A, Li R, et al. Pre-treatment T-cell subsets associate with fingolimod treatment responsiveness in multiple sclerosis. Sci Rep. 2020;10(1):356.

24. Li R, Rezk A, Ghadiri M, et al. Dimethyl fumarate treatment mediates an antiinflammatory shift in B cell subsets of patients with multiple sclerosis. J Immunol. 2017;198(2):691-698.

25. Jenks SA, Cashman KS, Zumaquero E, et al. Distinct effector B cells induced by unregulated toll-like receptor 7 contribute to pathogenic responses in systemic lupus erythematosus. Immunity. 2018;49(4):725-e6.

26. Claes N, Fraussen J, Vanheusden M, et al. Age-associated B cells with proinflammatory characteristics are expanded in a proportion of multiple sclerosis patients. J Immunol. 2016;197(12):4576-4583.

27. Woodruff MC, Ramonell RP, Nguyen DC, et al. Extrafollicular B cell responses correlate with neutralizing antibodies and morbidity in COVID-19. Nat Immunol. 2020;21(12):1506-1516.

28. Duddy M, Niino M, Adatia F, et al. Distinct effector cytokine profiles of memory and naive human B cell subsets and implication in multiple sclerosis. J Immunol. 2007; 178(10):6092-6099.

29. Bar-Or A, Fawaz L, Fan B, et al. Abnormal B-cell cytokine responses a trigger of T-cellmediated disease in MS?. Ann Neurol. 2010;67(4):452-461.

30. Yoshizaki A, Miyagaki T, DiLillo DJ, et al. Regulatory B cells control T-cell autoimmunity through IL-21-dependent cognate interactions. Nature. 2012;491(7423) 264-268.

31. Li R, Rezk A, Miyazaki Y, et al. Proinflammatory GM-CSF-producing B cells in multiple sclerosis and B cell depletion therapy. Sci Transl Med. 2015;7(310):310ral66.

32. Li R, Rezk A, Healy LM, et al. Cytokine-defined B cell responses as therapeutic targets in multiple sclerosis. Front Immunol. 2015;6:626

33. Li R, Rezk A, Li H, Gommerman JL, Prat A, Bar-Or A. Antibody-independent function of human B cells contributes to antifungal T cell responses. J Immunol. 2017; 198(8):3245-3254

34. Mauri C, Menon M. Human regulatory B cells in health and disease: therapeutic potential. J Clin Invest. 2017;127(3):772-779.

35. Arkatkar T, Du SW, Jacobs HM, et al. B cell-derived IL-6 initiates spontaneous germinal center formation during systemic autoimmunity. J Exp Med. 2017;214(11) 3207-3217.

36. Getahun A, Cambier JC. Non-antibody-secreting functions of B cells and their contribution to autoimmune disease. Annu Rev Cel Dev Biol. 2019;35:337-356. 
37. Bar-Or A, Li R. Cellular immunology of relapsing multiple sclerosis: interactions, checks, and balances. Lancet Neurol. 2021;20(6):470-483.

38. Papachroni KK, Ninkina N, Papapanagiotou A, et al. Autoantibodies to alphasynuclein in inherited Parkinson's disease. J Neurochem. 2007;101(3):749-756.

39. Shalash A, Salama M, Makar M, et al. Elevated serum alpha-synuclein autoantibodies in patients with Parkinson's disease relative to Alzheimer's disease and controls. Front Neurol. 2017;8:720.

40. Horvath I, Iashchishyn IA, Forsgren L, Morozova-Roche LA. Immunochemical detection of alpha-synuclein autoantibodies in Parkinson's disease: correlation between plasma and cerebrospinal fluid levels. ACS Chem Neurosci. 2017;8(6):1170-1176.

41. Li X, Koudstaal W, Fletcher L, et al. Naturally occurring antibodies isolated from PD patients inhibit synuclein seeding in vitro and recognize Lewy pathology. Acta Neuropathol. 2019;137(5):825-836.

42. Molnarfi N, Schulze-Topphoff U, Weber MS, et al. MHC class II-dependent B cell APC function is required for induction of CNS autoimmunity independent of myelinspecific antibodies. J Exp Med. 2013;210(13):2921-2937.

43. Hong S, Zhang Z, Liu H, et al. B cells are the dominant antigen-presenting cells that activate naive $\mathrm{CD} 4(+) \mathrm{T}$ cells upon immunization with a virus-derived nanoparticle antigen. Immunity. 2018;49(4):695-708 e694.

44. Shen P, Fillatreau S. Antibody-independent functions of B cells: a focus on cytokines. Nat Rev Immunol. 2015;15(7):441-451.

45. Alvarez-Luquin DD, Arce-Sillas A, Leyva-Hernandez J, et al. Regulatory impairment in untreated Parkinson's disease is not restricted to tregs: other regulatory populations are also involved. J Neuroinflammation. 2019;16(1):212.

46. Kedmi M, Bar-Shira A, Gurevich T, Giladi N, Orr-Urtreger A. Decreased expression of B cell related genes in leukocytes of women with Parkinson's disease. Mol Neurodegener. 2011;6:66.

47. Stevens $\mathrm{CH}$, Rowe D, Morel-Kopp MC, et al. Reduced T helper and B lymphocytes in Parkinson's disease. J Neuroimmunol. 2012;252(1-2):95-99.

48. Zhao X, Jin T, Zheng C, Ma D, Zhang Y. Imbalance of circulating Tfh/Tfr cells in patients with Parkinson's disease. Front Neurol. 2020;11:572205.

49. Barr TA, Shen P, Brown S, et al. B cell depletion therapy ameliorates autoimmune disease through ablation of IL-6-producing B cells. J Exp Med. 2012;209(5):1001-1010.

50. Rauch PJ, Chudnovskiy A, Robbins CS, et al. Innate response activator B cells protect against microbial sepsis. Science. 2012;335(6068):597-601.
51. Vinuesa CG, Linterman MA, Yu D, MacLennan IC. Follicular helper T cells. Annu Rev Immunol. 2016;34:335-368.

52. Cosentino M, Fietta AM, Ferrari M, et al. Human CD4+CD25+ regulatory T cells selectively express tyrosine hydroxylase and contain endogenous catecholamines subserving an autocrine/paracrine inhibitory functional loop. Blood. 2007;109: 632-642.

53. Nakano K, Higashi T, Takagi R, Hashimoto K, Tanaka Y, Matsushita S. Dopamine released by dendritic cells polarizes Th2 differentiation. Int Immunol. 2009;21(6): 645-654.

54. Papa I, Saliba D, Ponzoni M, et al. TFH-derived dopamine accelerates productive synapses in germinal centres. Nature. 2017;547(7663):318-323.

55. Basu B, Sarkar C, Chakroborty D, et al. D1 and D2 dopamine receptor-mediated inhibition of activated normal $\mathrm{T}$ cell proliferation is lost in jurkat $\mathrm{T}$ leukemic cells. J Biol Chem. 2010;285(35):27026-27032.

56. Yan Y, Jiang W, Liu L, et al. Dopamine controls systemic inflammation through inhibition of NLRP3 inflammasome. Cell. 2015;160(1-2):62-73.

57. Santambrogio L, Lipartiti M, Bruni A, Dal Toso R. Dopamine receptors on human Tand B-lymphocytes. J Neuroimmunol. 1993;45(1-2):113-119.

58. Arce-Sillas A, Sevilla-Reyes E, Alvarez-Luquin DD, et al. Expression of dopamine receptors in immune regulatory cells. Neuroimmunomodulation. 2019;26(3):159-166.

59. Gonzalez H, Contreras F, Prado C, et al. Dopamine receptor D3 expressed on CD4+ $\mathrm{T}$ cells favors neurodegeneration of dopaminergic neurons during Parkinson's disease. J Immunol. 2013;190(10):5048-5056.

60. Contreras F, Prado C, Gonzalez H, et al. Dopamine receptor D3 signaling on CD4+ $\mathrm{T}$ cells favors Th1- and Th17-mediated immunity. J Immunol. 2016;196(10): 4143-4149.

61. Osorio-Barrios F, Prado C, Contreras F, Pacheco R. Dopamine receptor D5 signaling plays a dual role in experimental autoimmune encephalomyelitis potentiating Th17mediated immunity and favoring suppressive activity of regulatory T-cells. Front $\mathrm{Cel}$ Neurosci. 2018;12:192.

62. Meredith EJ, Holder MJ, Rosén A, et al. Dopamine targets cycling B cells independent of receptors/transporter for oxidative attack: implications for non-Hodgkin's lymphoma. Proc Natl Acad Sci USA. 2006;103(36):13485-13490.

63. Julien C, Hache G, Dulac M, et al. The clinical meaning of levodopa equivalent daily dose in Parkinson's disease. Fundam Clin Pharmacol. 2021;35(3):620-630. 


\title{
Neurology \\ Neuroimmunology \& Neuroinflammation
}

\author{
Abnormal B-Cell and Tfh-Cell Profiles in Patients With Parkinson Disease: A \\ Cross-sectional Study \\ Rui Li, Thomas Francis Tropea, Laura Rosa Baratta, et al. \\ Neurol Neuroimmunol Neuroinflamm 2022;9; \\ DOI 10.1212/NXI.0000000000001125
}

This information is current as of December 26, 2021

\section{Updated Information \& Services}

References

Subspecialty Collections

Permissions \& Licensing

Reprints including high resolution figures, can be found at:

http://nn.neurology.org/content/9/2/e1125.full.html

This article cites 62 articles, 15 of which you can access for free at: http://nn.neurology.org/content/9/2/e1125.full.html\#\#ref-list-1

This article, along with others on similar topics, appears in the following collection(s):

All Immunology

http://nn.neurology.org//cgi/collection/all_immunology

Parkinson's disease/Parkinsonism

http://nn.neurology.org//cgi/collection/parkinsons_disease_parkinsonis $\mathrm{m}$

Information about reproducing this article in parts (figures,tables) or in its entirety can be found online at:

http://nn.neurology.org/misc/about.xhtml\#permissions

Information about ordering reprints can be found online:

http://nn.neurology.org/misc/addir.xhtml\#reprintsus

Neurol Neuroimmunol Neuroinflamm is an official journal of the American Academy of Neurology.

Published since April 2014, it is an open-access, online-only, continuous publication journal. Copyright

Copyright $\odot 2021$ The Author(s). Published by Wolters Kluwer Health, Inc. on behalf of the American

Academy of Neurology.. All rights reserved. Online ISSN: 2332-7812.

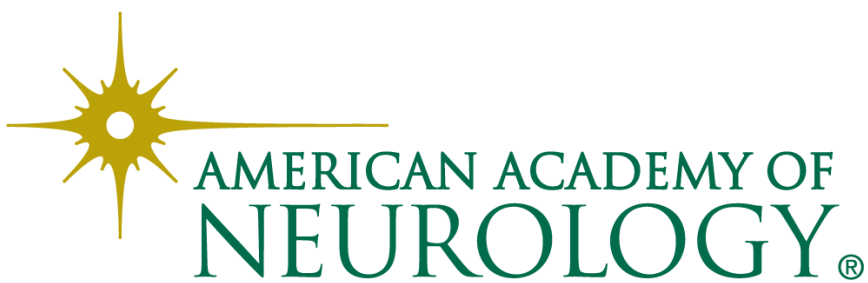

